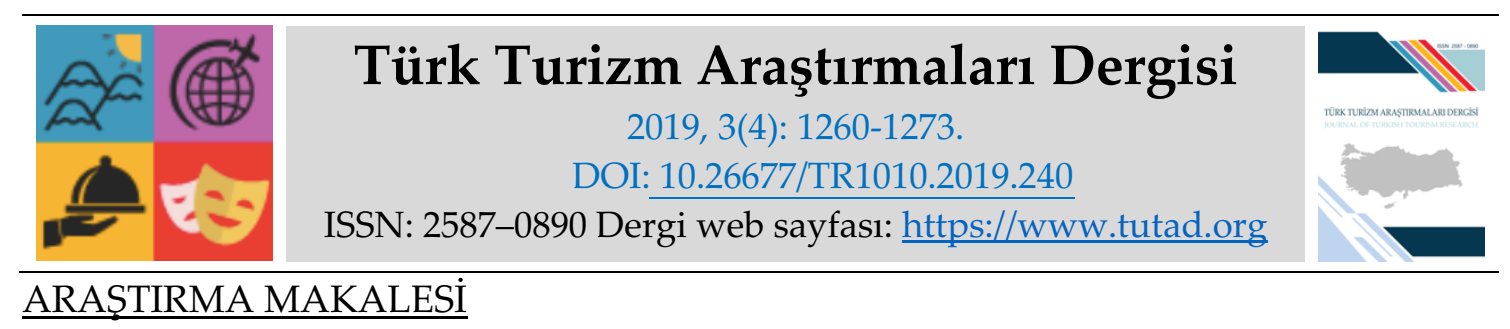

\title{
Sağlık Turizmi İşletmelerinde Müşteri Memnuniyeti (Samsun ve Sivas İli Karşılaştırması) ${ }^{1}$
}

Dr. Öğr. Üyesi Naim KARAGÖZ, Sivas Cumhuriyet Üniversitesi, Tip Fakültesi, Halk Sağlığ Bölümü, Sivas, e-posta: nkaragoz@cumhuriyet.edu.tr

ORCID: https://orcid.org/0000-0002-6456-1128

Alev ÖZTÜRK, Sivas Cumhuriyet Üniversitesi, Sosyal Bilimler Enstitüsü, Sivas, e-posta: alevozgur5885@gmail.com, ORCID: https://orcid.org/0000-0002-5972-7568

\section{Öz}

Sağllk turizmi dünyanın belli ülkelerinde ve ülkemizde gelişim göstermekte olan bir turizm türüdür. Ülkemizdeki termal kaynakların zenginliği, sağlık turizminin gelişimi açısından önem taşıdığı gerçeğinden hareketle araştırma alanı olarak sağlık turizm işletmeleri seçilmiş ve bu işletmelerde müşteri memnuniyetinin ölçülmesi ve illerin karşılaştırılması sonucu ortaya çıkacak sonuçların değerlendirmesi yapılmıştır. Bu kapsamda yürütülen araştırmanın kavramsal çerçevesini sağlık kavramı, sağlık turizmi ve müşteri memnuniyeti oluşturmakta, araştırmanın örneklemini ise Sivas ve Samsun illerindeki sağlık turizmi işletmeleri oluşturmaktadır. Bu araştırmada veri toplamak amacı ile anket yöntemi kullanılmıştır. Araştırmada kullanılan ve müşteriye yönelik oluşturulan anketlerin analizi için, SPSS 23 programından yararlanılmıştır. Toplanan veriler öncelikli olarak SPSS'e aktarılmış. Değişkenlere ilişkin veriler, frekans ve yüzde değerleri, aritmetik ortalamalar kullanılarak değerlendirilmiştir. Konaklama yapılan il ile genel müşteri memnuniyeti, heveslilik ve empati faktörleri arasında anlamlı bir farklılık bulunmuştur. Genel olarak müşterilerin sağlık turizmi işletmelerindeki memnuniyet düzeyleri olumlu yönde görülmüştür.

Anahtar Kelimeler: Sağlık Turizmi, İşletme, Sağlık, Müşteri Memnuniyeti, Samsun, Sivas.

Makale Gönderme Tarihi: 27.07.2019

Makale Kabul Tarihi: 06.10.2019

\section{Önerilen Atıf:}

Karagöz, N. ve Öztürk, A. (2019). Sağllk Turizmi İşletmelerinde Müşteri Memnuniyeti (Samsun ve Sivas İli Karşılaştırması), Türk Turizm Araştırmaları Dergisi, 3(4): 1260-1273.

(c) 2019 Türk Turizm Araştırmaları Dergisi.

\footnotetext{
${ }^{1}$ Bu çalışma 19 Haziran 2019 tarihinde 2. yazar tarafından hazırlanan tez çalışmasından derlenmiştir.
} 


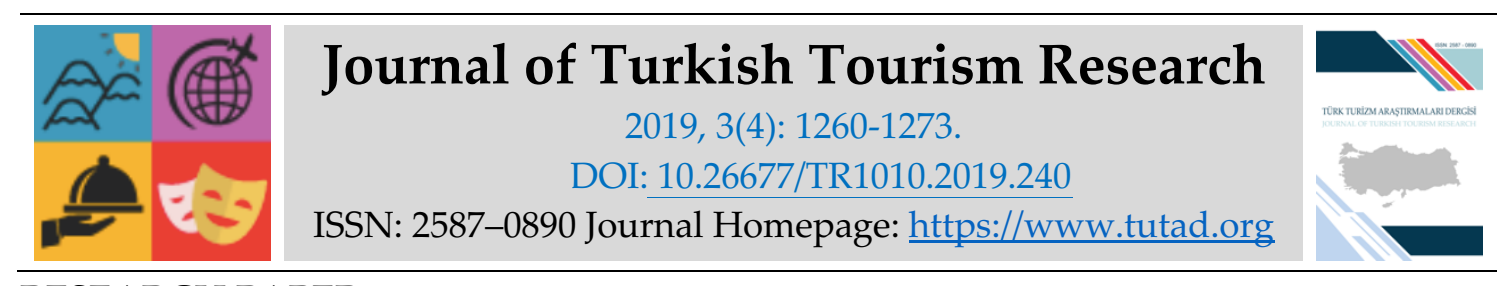

RESEARCH PAPER

\title{
Customer Satisfaction in Health Tourism Business (Comparison of Samsun and Sivas Province)
}

Assistant Prof. Dr. Naim KARAGÖZ, Sivas University, Faculty of Medicine, Department of Public Health, Sivas, e-mail: nkaragoz@cumhuriyet.edu.tr

ORCID: https://orcid.org/0000-0002-6456-1128

Alev ÖZTÜRK, Sivas Cumhuriyet University, Social Sciences Institute, Sivas, e-mail: alevozgur5885@gmail.com, ORCID: https://orcid.org/0000-0002-5972-7568

\begin{abstract}
Health tourism is a kind of tourism which is developing in certain countries and countries of the world. In the light of the fact that the richness of thermal resources in our country is important for the development of health tourism, health tourism enterprises were chosen as the research area and the results of the evaluation of the customer satisfaction and the comparison of the provinces were evaluated. The conceptual framework of the research carried out within this scope constitutes the concept of health, health tourism and customer satisfaction, while the sample of the study consists of health tourism enterprises in the provinces of Sivas and Samsun. In this study, survey method was used to collect data. SPSS 23 program was used for the analysis of the questionnaires which were used in the research. The collected data was transferred to SPSS. The data, frequency and percentage values of the variables were evaluated using arithmetic means. A significant difference was found between the province and the general customer satisfaction, enthusiasm and empathy factors. In general, the satisfaction levels of the customers in the health tourism enterprises were positive.
\end{abstract}

Keywords: Health Tourism, Business, Health, Customer Satisfaction, Samsun, Sivas.

Received: 27.07.2019

Accepted: 06.10.2019

\section{Suggested Citation:}

Karagöz, N. and Öztürk, A. (2019). Customer Satisfaction in Health Tourism Business (Comparison of Samsun and Sivas Province), Journal of Turkish Tourism Research, 3(4): 1260-1273.

(C) 2019 Türk Turizm Araştırmaları Dergisi. 


\section{Gíriş}

Günümüzde kentleşme ve yoğun iş temposu nedeniyle birçok insan olumsuz yaşam şartlarından etkilenmektedir. Kentleşmenin ve iş stresinin vermiş olduğu psikolojik olumsuzluklar ve fiziksel rahatsızlıklar kişilerin kendilerini kötü hissetmelerine neden olmakta ve bir süreliğine dahi olsa başka bir bölgeye seyahat etmelerini arzu etmelerini sağlamaktadır. Bireyler psikolojik veya fiziksel sağlıklarını yerine getirebilmek amacıyla turizm faaliyetlerini tercih edebilmektedirler (Sayın, Yeginboy ve Yüksel 2017). Sağlı̆ıın "Sağlık sadece hastalık veya sakatlık halinin olmayışı değil, bedensel, ruhsal ve sosyal yönden tam bir iyilik halidir." olarak tanımlanması da bu girişimi desteklemektedir (Oyur Çelik vd., 2009: 164).

Turizmin genel tanımının içeriğinde yer değiştirme vardır. Bu yer değiştirme doğal, tarihi, kültürel ve toplumsal yapısı kişinin alışık olduğunun dışındaki bir başka yere gitme biçiminde kendini gösterir. Bazı sosyologlar tarafından evrensel büyük bir göç hareketi olarak nitelendirilen turizm; Uluslararası Turizm Akademisi (L'Academie Internationaledu Tourisme) tarafından yapılan bir tanıma göre aslında bir bilgi eylemidir. Diğer sosyologlar da turizm kavramının içeriğinde yer alan fiziki ve sosyal mekanda sürekli hareket eden evrensel bir göç ifadesini yeterli görmezler. Bazı sosyologlar içinde bulunduğumuz çağa "Serbest Zamanlar Çağı" adını vermektedirler. Özellikle kişinin çalışma saati dışındaki toplumsal etkinliği ve rekreasyonun faydası açısından tekdüze disiplinli ve denetimli yaşamın getirebileceği toplumsal problemlerden ve sinırlamalardan belirli bir süre uzak kalmak ve bu süreyi eğlenerek ve dinlenerek geçirmek ihtiyacı bireyler arasında her geçen gün biraz daha artmaktadır. İşte bu istek ve beklentiler turisti yaratan etkenlerin en başında gelen dürtülerdir (Berber, 2003: 206).

Günümüzde dünyanın birçok ülkesinden insanlar tatil keyfini yaşamak ve makul bir fiyatla sağlık elde etmek için başka ülkelere seyahat etmek istemektedirler. Bu ise sağlık turizmini ortaya çıkarmaktadır. Sağlık turizmi, turizmin bir alt kategorisi olarak kabul edilmekte olup, önemli bir alternatif turizm çeşididir. Tedavi amacı ile yapılan seyahatlere kısaca sağlık turizmi denilmektedir. Buna göre sağlık turizmi, fiziksel tedaviye ve rehabilitasyona ihtiyacı olan hastaları kullanarak sağlık kuruluşlarının büyümesine yardımcı olmaktadır. Fakat sağlık turizmi sadece hasta insanlar tarafından eski sağlığına kavuşmak için gerçekleştirilen bir turizm hareketi değildir. Aynı zamanda kişiler güzellik bakımı, sağlıklı beslenme / diyet, gevşeme / meditasyon ve zihinsel aktivite gibi faaliyetler içinde sağlık turizmi alanında hizmet veren işletmelere başvurmaktadırlar. Bu bağlamda genel olarak sağlık turizmi; insanların bir süreliğine (genellikle 21 gün) doğal kaynaklı hizmet veren turistik bir tesise giderek burada konaklaması, eğlenmesi, beslenme gibi zorunlu ihtiyaçları karşılaması ve en önemlisi mevcut sağlığını koruması veya bozulan sağlığın iyileştirilmesi için kür uygulaması gibi hareketler sonucu doğan seyahatlerdir (Aydın, 2012: 92).

Sağlık turizmi faaliyetlerinde son yıllarda önemli farklılıklar görülmektedir. Geçmişte az gelişmiş veya gelişmemiş ülkelerden gelişmiş ülkelere doğru seyahat yapılmakla beraber günümüzde az gelişmiş ülkelere sağlık turizmi nedeniyle seyahat daha fazla yapılmaktadır. Az gelişmiş ülkelere sağlık turizmi nedeniyle seyahat yapılmasını en önemli nedenlerinden biri ülkelerde sağlık hizmetleri kapsamında maliyetlerin daha düşük olmasıdır (Barca, Akdeve ve Gedik Balay, 2013: $111)$.

Sağlıklı yaşam turizmi, gelişmiş bir pazar alanı haline gelmiştir, öyle ki sadece termal tedavileri takip edenler için değil, aynı zamanda hastalıkları önlemek, fiziksel iyileştirme ve ruhsal dengeyi sağlamak, hatta bazıları için ise kültürel ve rahatlama programlarını kapsamaktadır. Bu anlamda, sağlık turizmi sadece çeşitliliğiyle ilgili olmayan aynı zamanda yüksek kaliteli ekipman ve altyapıya sahip, aynı zamanda tamamlayıcı eğlence aktiviteleri ile doğaya ve kültürel mirasa ve diğer bölgesel kaynaklara bağlantılı geniş bir ürün ve hizmet yelpazesi sunmaktadır (Ortiz ve 
Garcia, 2015: 21). Bu bağlamda; sağlık turizmi, termal turizm, welness (SPA) turizmi, medikal, yaşlı ve engelli turizmi olmak üzere beş başlı̆̆a ayrılmaktadır.

Türkiye Turizm Stratejileri 2023 hedefleri arasında Turizm Çeşitlendirilmesi Stratejisi başlığ altında alternatif turizm türleri arasında geliştirilmesi desteklenen turizm çeşitlerinden olan sağlık turizmi, bu kapsamda gördüğü özel desteklerle Türkiye'nin turizm çeşitliliğine katkı sağlamaktadır. Aynı zamanda sahip olduğu doğal kaynaklarıyla, sağlık turizminin geliştirebilmesine, sağllk turizmi işletmelerinde sunulan hizmetin müşterilere daha kaliteli ve etkin bir şekilde sunulmasıyla da önemli katkı sağlayacağı düşünülmekte olup bu nedenle sağlık turizmi işletmesi müşterilerinin; beklentilerinin, hizmet algılarının ve memnuniyet düzeylerinin bilinmesi işletme yönetimi açısından önem taşıyacağı öngörülmektedir.

Memnuniyet kavramı, tüketicinin tatmin olma tepkisi olarak tanımlanmaktadır. Daha geniş anlamiyla tüketici memnuniyetini "tatminkârlık ve tatmin olmama seviyeleri de dâhil olmak üzere, bir mal veya hizmetin bir özelliğinden veya bütün olarak kendisinden, tüketimle ilgili keyif verici tatminkârlık yargısı" olarak tanımlanmaktadır (Uygur ve Doğan, 2013: 35-36). Müşteri tatmini müşterinin satın alma eyleminden önceki beklentileri ile satın alma sonrası gerçekleşen ürün ve/veya hizmet performansının arasında oluşan farklılıkların değerlendirilmesine ilişkin tepki süreci olarak ele alınabilmektedir (Tütüncü ve İpekgil Doğan, 2003: 133).

Müşteri memnuniyeti işletme hangi alanda faaliyet gösteriyor olursa olsun, ekonomik kazanç sağlanması açısından önemlidir. Memnun olmuş müşteri sayesinde işletmeler hem sadık müşteriler kazanır hem de ağızdan ağza reklam vasıtasıyla daha büyük kitlelere ismini duyurur. Mal üretilen piyasalarda tüketiciler bir malı aldıklarında bunun maddi karşılığını öderler ve belli bir süre bu üründen fayda sağlarlar. Ancak hizmet işletmelerinde özellikle de sağlık ve termal işletmelerde misafirler ödedikleri parasal değerin karşllı̆ıında, sağlık işletmelerinden sağlıklarının iyileşmesini ve zindeliklerinin devam etmesini beklemektedirler. Bu kadar önemli bir konuda müşterilerin isteklerinin, beklentilerinin, şikâyetlerinin ve memnun oldukları durumların detaylı olarak değerlendirilmesi son derece önemlidir (Ünal ve Demirel, 2011: 138).

Termal turizm işletmeleri için de mevcut müşteriyi elde tutmanın ve müşteri sadakati sağlamanın en önemli şartlarından birisi müşteri memnuniyetinin yaratılmasıdır. Çünkü, memnun müşterinin tesisin ürettiği hizmete bağlllık göstermesi ve memnun kaldığı bu hizmet sayesinde tesisle uzun yıllar ilişkisini sürdürmesi beklenmektedir. İşletmeler, ürünlerine ve hizmetlerini daha iyi üreterek müşterilerine sundukları taktirde müşteri memnuniyetini temin edebilmektedirler; böylece, tesis ile müşterileri arasında duygusal bir bağ oluşup mevcut müşteriyi elde tutma eylemi gerçekleşmektedir. Müşteri memnuniyetinin sağlanması için müşterilerin gerçekte neye istek ve ihtiyaç duyduklarının ve işletmeden beklentilerinin bilinmesi gerekmektedir (Sandıkçı ve Gürpınar, 2008: 107)

Turizm işletmelerinin, müşterilerinin talepleri doğrultusunda mal ve hizmet üretmeleri, müşterileri memnuniyetini arttırmakta ve buna bağlı olarak da müşterilerin işletmeye bağlllıkları artmaktadır. Bu sayede işletmeler de ticari faaliyetlerinin devamlılığını sağlayabilmektedirler (Aymankuy, Akgül ve Can Akgül, 2012: 225).

\section{METERYAL VE METOD}

$\mathrm{Bu}$ bölümde, araştırmanın; tasarımı, evreni ve örneklem seçimi, seçilen örneklem üzerine uygulanan veri toplama araçları, teknikleri ve istatistiki yöntemlerle test edilmiş araştırmadan derlenen analizlerle ilgili bilgilere yer verilmektedir. 


\section{Verilerin Analizi}

Veriler, SPSS 23 programı kullanılarak yüzde dağılım, frekans, aritmetik ortalama, standart sapma, t-testi, ANOVA, Crosstabs ve Korelasyon testi ile değerlendirmeye tabi tutularak elde edilerek yorumlanmıştır.

Altunışık vd., (2005:116) göre alfa değeri 0 ile 1 arasında değerler alır ve kabul edilebilir bir değerin en az 0,7 olması arzu edilir. Ancak inceleme türü çalışmalarda bu değerin 0,5' e kadar makul kabul edilebileceği de bazı araştırmacılarca öngörülmektedir. Yapılan güvenirlik analizi sonucunda boyutlara yönelik sonuçlar fiziksel imkanlar 0,858, güven düzeyi 0,852, heveslilik 0,859 , yeterlilik 0,844 , empati 0,868 çıkmıştır. Güvenirlilik katsayısında ise genel müşteri memnuniyeti 0,892 ile en yüksek katsayı değerini almıştır. Bu sonuç, ölçeğin güvenilirlik sınırları içinde bulunduğunu göstermektedir.

\section{Araştırmanın Amacı ve Hipotezleri}

Ülkemizdeki termal kaynakların zenginliğinin, sağlık turizminin gelişimi açısından önem taşıdığı gerçeğinden hareketle araştırma alanı olarak sağlık turizm işletmeleri seçilmiş, bu işletmelerde müşteri memnuniyetinin ölçülmesi ve illerin karşılaştırılması sonucu ortaya çıkacak sonuçların değerlendirmesi amaçlanmıştır.

Araştırma hipotezine ilişkin bilgiler olarak sadece $\mathbf{H}_{1}$ hipotezlerine yer verilmiştir.

\section{Müşteri Memnuniyetine İlişkin Hipotezler Şu Şekildedir:}

- Konaklanan yer ile genel müşteri memnuniyeti arasında anlamlı bir farklılık bulunmaktadır.

- Konaklanan yer ile yeterlilik boyutu arasında anlamlı bir farklılık vardır.

- Konaklanan yer ile fiziksel imkânlar arasında anlamlı bir farklılık vardır.

- Konaklanan yer ile güven düzeyi arasında anlamlı bir farklılık vardır.

- Konaklanan yer ile heveslilik boyutu arasında anlamlı bir farklılık vardır.

- Konaklanan yer ile empati boyutu arasında anlamlı bir farklılık vardır.

\section{Evren ve Örneklem}

Yapılan bu araştırmanın evrenini; Samsun ve Sivas illerindeki Sağlık Bakanlığı işletme belgeli termal otellerde konaklayan müşteriler oluşturmaktadır. Tanımlanan evrendeki her elemanın, "eşit" ve "bağımsız" seçilme şansına sahip olması, araştırmanın güvenilirliği açısından oldukça önemlidir (Altunışık vd., 2005: 142).

Bu nedenle kolayda örnekleme ile örneklem belirlenmiştir. Evrenin büyüklügü, zaman ve maliyet imkânlarının kısıtlı olması gibi nedenlerden dolayı, anket ulaşılabilen 225 otel müşterisi ile yüz yüze yapılmıştır. Bunlardan veri sağlamaya elverişli 189 anket formu ile sonuçlara ulaşılmıştır.

Turizm, ülkenin her bölgesine yayılmış olmasından dolayı, turizmle ilgili araştırmalar yapılırken çalışma alanları sınırlandırılmaktadır. Araştırma evrenin oldukça geniş bir alana yayılması, araştırmayı Sivas ve Samsun sağlık turizmi işletmelerinde konaklayan müşteriler ile sınırlandırmıştır. Ayrıca araştırma kapsamında hedeflenen anket sayılarına istenilen ölçüde ulaşılamamıştır, bunun sebebi otellerde konaklayan müşterilerin anketlere tüm çabalara rağmen gerekli ilgiliyi göstermeyişleridir. Araştırma kapsamında Sivas ili sınırlarında bulunan Kangal Balıklı Çermik, Sivas Termal Otel ile Samsun ili sınırlarındaki Havza ilçesindeki Ancere Termal 
Otelinde gerçekleşmiştir. Samsun Lâdik'te bulunan Hilas Termal Resort otel genel müdürü anket yapılmasına izin vermediği için veriler toplanamamıştır.

\section{Verilerin Toplanmasi}

Araştırmada anket uygulaması gerçekleştirilmiştir. Anket formunda, müşterilerin genel memnuniyetlerini anlamaya yönelik 1- "Kesinlikle Karşılamadı", 5 "Kesinlikle Karşıladı" arasında beşli Likert sorularından oluşan bir değerlendirme imkânı tanınmıştır.

Anket formunun ikinci bölümünde müşterilerin demografik özelliklerinin tespit edilmesine yönelik (Cinsiyet, yaş, eğitim durumu, medeni durum, aylık ortalama gelir, konakladığı yer ve mesleği) çoktan seçmeli altı soru sorulmuş ve müşterilerden kendilerine uygun olan şıkk1 seçmeleri istenmiştir. Değerlendirme sorularında beşli Likert ölçeği kullanılmıştır. Araştırmayı uygulayacak müşterilerden işaretlemeyi yapmaları için her bir soruya (1) Kesinlikle Katılmiyorum, (2) Katılmıyorum, (3) Ne Katılıyorum Ne Katılmıyorum (4) Katılıyorum, (5) Kesinlikle Katıllyorum, seçeneklerini işaretleyerek değerlendirmeleri istenmiştir.

\section{BULGULAR VE DEĞERLENDİRME}

Araştırmada elde edilen bulgular aşağıda verilmiştir;

Tablo 1. Müşterilerin Demografik Özelliklerinin Frekans ve Yüzde Dağılımları

\begin{tabular}{|c|c|c|c|c|c|c|c|}
\hline \multicolumn{2}{|c|}{ Demografik Özellikler } & \multirow{2}{*}{$\begin{array}{l}\text { (f) } \\
99\end{array}$} & \multirow{2}{*}{$\begin{array}{l}(\%) \\
52,4 \\
\end{array}$} & \multicolumn{2}{|c|}{ Demografik Özellikler } & \multirow{2}{*}{$\begin{array}{l}\text { (f) } \\
14 \\
\end{array}$} & \multirow{2}{*}{$\begin{array}{l}(\%) \\
7,4\end{array}$} \\
\hline \multirow{3}{*}{ Cinsiyet } & Kadın & & & \multirow{9}{*}{$\begin{array}{l}\text { Gelir } \\
\text { Durumu }\end{array}$} & Gelirim yok & & \\
\hline & Erkek & 90 & 47,6 & & $1-1604$ & 21 & 11,1 \\
\hline & Toplam & 189 & 100 & & $1605-2105$ & 29 & 15,3 \\
\hline \multirow{6}{*}{ Yaş } & $18-25$ & 25 & 13,2 & & $2106-2606$ & 23 & 12,2 \\
\hline & $26-33$ & 35 & 18,5 & & $2607-3107$ & 25 & 13,2 \\
\hline & $34-41$ & 53 & 28,0 & & $3108-3608$ & 22 & 11,6 \\
\hline & $42-49$ & 49 & 25,9 & & $3609-4109$ & 24 & 12,7 \\
\hline & 50 ve üstü & 27 & 14,3 & & 4110 ve üstü & 31 & 16,4 \\
\hline & Toplam & 189 & 100,0 & & Toplam & 189 & 100,0 \\
\hline \multirow{3}{*}{$\begin{array}{l}\text { Konaklama } \\
\text { Yapilan } \\
\text { Yer } \\
\end{array}$} & Samsun & 79 & 41,8 & \multirow{10}{*}{ Meslek } & Memur & 30 & 15,9 \\
\hline & Sivas & 110 & 58,2 & & Emekli & 28 & 14,8 \\
\hline & Toplam & 189 & 100,0 & & İşçi & 19 & 10,1 \\
\hline \multirow{7}{*}{$\begin{array}{l}\text { Eğitim } \\
\text { Durumu }\end{array}$} & İlköğretim & 17 & 9,0 & & $\begin{array}{l}\text { Serbest } \\
\text { meslek }\end{array}$ & 34 & 18,0 \\
\hline & Ortaöğretim & 64 & 33,9 & & Özel sektör & 39 & 20,6 \\
\hline & Ön Lisans & 47 & 24,9 & & Ev hanımı & 21 & 11,1 \\
\hline & Lisans & 48 & 25,4 & & Öğrenci & 11 & 5,8 \\
\hline & $\begin{array}{l}\text { Yüksek } \\
\text { Lisans }\end{array}$ & 10 & 5,3 & & Çalışmıyor & 2 & 1,1 \\
\hline & Doktora & 3 & 1,6 & & Diğer & 5 & 2,6 \\
\hline & Toplam & 189 & 100,0 & & Toplam & 189 & 100,0 \\
\hline
\end{tabular}


Tablo 1'e bakıldığında uygulanan üç otelde müşterilerin \%52,4' ünü kadınların, 47,6' sını ise erkeklerin oluşturduğu öne çıkmaktadır. Otelde konaklayanların büyük çoğunluğunu \% 28,0 ile 34-41 yaş arası müşterinin oluşturmakta ve bunu \%25,9 ile 42-49 yaş arası takip etmektedir. Burada görülmektedir ki konaklayan müşterilerin yarısından çoğu orta yaş kesiminden oluşmaktadır. Müşterilerin gelirlerinin bir kısmı \%16,4 ile 4110 ve üstündedir. Daha sonrasında ise sirayla \%15,3 ile 1605-2105 arasında, \%13,2 ile 2607-3107 arasında, \%12,2 ile 2106-2606 arasında olduğu görülmektedir. Burada hemen hemen her gelir grubundan müşterinin eşit şekilde konaklamış olduğu görülmektedir. Müşterilerin eğitim durumlarına bakıldığında ise müşterilerin \% 33,9' unun ortaöğretim mezunu oldukları, \% 25,4' ünün lisans, \%24,9' unun ön lisans, \%9'unun ilköğretim ve \% 6,9'unun ise lisansüstü mezunu oldukları görülmektedir.

Müşterilerin mesleklerinde ise \%20,6'sını özel sektör, \%18'ini özel sektör ve \%15,9'unu memur grubu oluşturmaktadır. Bu meslek gruplarını \% 14,8 ile Emekli, \%11,1 ile Ev Hanımı, \% 10,1 ile İşçi Meslek grupları izlemektedir. Meslek gruplarında ise en az oranı \% 1,1 ile çalışmayanlar oluşturmaktadır.

Tablo 2. Otelin Genel Olarak Olanakları ve Hizmetinden Memnuniyet Durumu ile Konaklama Yapılan Yere İlişkin Çapraz Tablo Analizi

$\begin{array}{lccccccc}\begin{array}{l}\text { Bu otelin genel olarak olanakları } \\ \text { ve hizmetinden memnunum }\end{array} & \mathbf{1} & \mathbf{2} & \mathbf{3} & \mathbf{4} & \mathbf{5} & \text { Toplam } \\ \text { Samsun } & \mathbf{( f )} & 1 & 0 & 7 & 38 & 33 & 79 \\ & \mathbf{( \% )} & 1,3 \% & 0,0 \% & 8,9 \% & 48,1 \% & 41,8 \% & 100,0 \% \\ \text { Sivas } & (\mathbf{f}) & 2 & 24 & 20 & 22 & 42 & 110 \\ & (\mathbf{\%}) & 1,8 \% & 21,8 \% & 18,2 \% & 20,0 \% & 38,2 \% & 100,0 \%\end{array}$

İllerin karşılaştırmasına yönelik yapılan çapraz tablo analizinde, bu otelin genel olarak olanakları ve hizmetinden memnunum ifadesine verilen cevaplarda genel memnuniyet açısından Sivas ilinde memnun müşteri oranının $\% 58,2$, kararsız $\% 18,2$ ve memnun olmayan müşteri oranının ise $\% 23,6$ olduğu görülmektedir. Samsun ilinde ise \%89,9 ile müşterilerin daha fazla memnun olduğu gözlemlenmiştir. Kararsız müşteri oranı \%8,9 ve memnun olmayan müşteri oranı ise $\% 1,3^{\prime}$ tür.

Tablo 3. Tekrar Gelecek Olsam Bu Oteli Tercih Ederim İfadesi ile Konaklama Yapılan Yere İlişkin Çapraz Tablo Analizi

$\begin{array}{lccccccc}\begin{array}{l}\text { Tekrar gelecek olsam bu oteli } \\ \text { tercih ederim }\end{array} & \mathbf{1} & \mathbf{2} & \mathbf{3} & \mathbf{4} & \mathbf{5} & \text { Toplam } \\ \text { Samsun } & (\mathbf{f}) & 1 & 1 & 14 & 26 & 37 & 79 \\ & (\mathbf{\%}) & 1,3 \% & 1,3 \% & 17,7 \% & 32,9 \% & 46,8 \% & 100,0 \% \\ \text { Sivas } & (\mathbf{f}) & 6 & 12 & 29 & 24 & 39 & 110 \\ & (\mathbf{\%}) & 5,5 \% & 10,9 \% & 26,4 \% & 21,8 \% & 35,5 \% & 100,0 \%\end{array}$

Müşterilerin otele tekrar gelme yargısına verdiği cevaplarda Sivas ilindeki otellere tekrar gelme konusunda $\% 26,4$ ile yaklaşık $4^{\prime}$ de 1 oranında kararsız kaldıkları görülmüştür. $\% 57,3$ oranında 
geri gelme ve \%16,4 oranında ise geri gelmeme görüşü belirtilmiştir. Samsun ilinde ise tekrar gelme oranı $\% 79,7$, kararsız kalma oranı $\% 17,7$ ve tekrar gelmeme oranı ise $\% 2,6^{\prime}$ dır. Buna göre Samsun ilindeki otellerin Sivas ilindeki otellere göre tekrar tercih edilme oranının daha fazla olduğu gözlemlenmiştir.

Tablo 4. Bu Oteli Başkalarına Öneririm İfadesi ile Konaklama Yapılan Yere İlişkin Çapraz Tablo Analizi

\begin{tabular}{lccccccc} 
Bu oteli başkalarına öneririm & $\mathbf{1}$ & $\mathbf{2}$ & $\mathbf{3}$ & $\mathbf{4}$ & $\mathbf{5}$ & Toplam \\
\multirow{2}{*}{ Samsun } & (f) & 1 & 2 & 16 & 25 & 35 & 79 \\
& (\%) & $1,3 \%$ & $2,5 \%$ & $20,3 \%$ & $31,6 \%$ & $44,3 \%$ & $100,0 \%$ \\
\multirow{2}{*}{ Sivas } & (f) & 7 & 15 & 21 & 27 & 40 & 110 \\
& (\%) & $6,4 \%$ & $13,6 \%$ & $19,1 \%$ & $24,5 \%$ & $36,4 \%$ & $100,0 \%$
\end{tabular}

Oteli başkalarına önerme konusunda ise Sivas ili \%60,9 ile konakladığı oteli başkalarına önermektedir. \%19,1 'lik kısım bu konuda kararsız kalmakta ve müşterilerin \%20'si ise Sivas ilindeki otelleri başlarına önermeyi düşünmemektedir. Samsun ilinde konaklayanların ise $\% 75,9^{\prime}$ u önermekte, \%20,3'ü kararsız kalmakta ve \%3,8'lik kısmı ise konakladığı oteli başkalarına önermemektedir. Buna göre oteli başkalarına önerme konusunda Samsun ilinde konaklayan oranı Sivas iline göre daha fazladır.

Tablo 5. Bu Otel Beklentilerimi Karşılamaktadır İfadesi ile Konaklama Yapılan Yere İlişkin Çapraz Tablo Analizi

$\begin{array}{cccccccc}\begin{array}{l}\text { Bu Otel Beklentilerimi } \\ \text { Karşılamaktadır }\end{array} & \mathbf{1} & \mathbf{2} & \mathbf{3} & \mathbf{4} & \mathbf{5} & \text { Toplam } \\ \text { Samsun } & \text { (f) } & 2 & 1 & 16 & 28 & 32 & 79 \\ & \text { (\%) } & 2,5 \% & 1,3 \% & 20,3 \% & 35,4 \% & 40,5 \% & 100,0 \% \\ \text { Sivas } & \text { (f) } & 9 & 18 & 15 & 27 & 41 & 110 \\ & \text { (\%) } & 8,2 \% & 16,4 \% & 13,6 \% & 24,5 \% & 37,3 \% & 100,0 \%\end{array}$

Sivas ilinde konaklayan müşterilerin beklentilerinin \%61,8 oranında karşılandığı, \%24,6 oranında karşılanmadığı ve \%13,6'sının ise karasız kaldığı görülmektedir. Samsun ilinde konaklayan müşterilerin beklentilerinin ise \%75,9 oranında karşılandığı, \%20,3 oranında karasız kalındığı ve \%3,8 oranında karşılanmadığı görülmektedir. Otel beklentileri tablosunda her iki il için de 
beklentileri karşılama oranının yüksek olduğu, müşterilerin bu hususta pozitif düşündükleri görülmüştür.

Tablo 6. Tedavi Ünitelerinin Donanımının Kullanım Amacına Uygun Olması İfadesi ile Konaklama Yapılan Yere İlişkin Çapraz Tablo Analizi

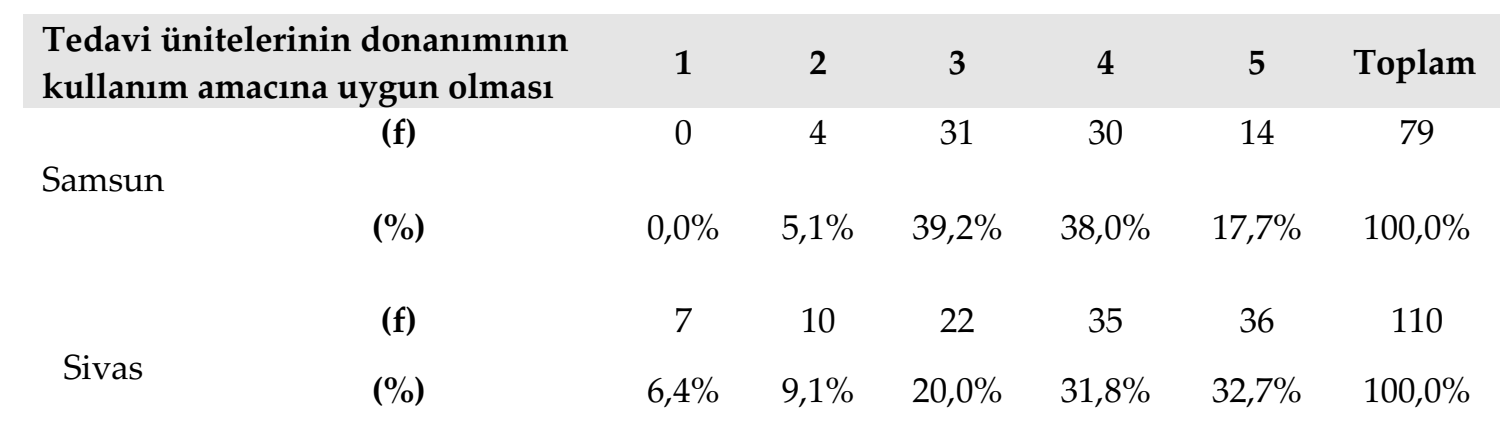

Sivas ilinde konaklayan müşteriler $\% 64,5$ oranla tedavi ünitelerinin donanımının kullanım amacına uygun olduğunu, \%15,5'lik kısmının uygun olmadığını düşündükleri ve \%20 oranında müşterinin ise karasız kaldığ 1 görülmektedir. Ancak Samsun ilinde bu oranın \%55,7 ile daha düşük olduğu görülmektedir. Samsun ilinde konaklayan müşterilerin $\% 39,2$ ‘lik gibi büyük bir oranın bu konuda kararsız kaldığı ve \%5,1'inin ise uygun olmadığını belirttiği görülmektedir.

Tablo 7. Termal Suyun Kalitesinin Kullanım Amacına Yeterli Derecede Uygunluğu İfadesi ile Konaklama Yapılan Yere İlişkin Çapraz Tablo Analizi

\begin{tabular}{|c|c|c|c|c|c|c|}
\hline $\begin{array}{l}\text { Termal suyun kalitesinin kullanım } \\
\text { amacına yeterli derecede uygunluğu }\end{array}$ & 1 & 2 & 3 & 4 & 5 & Toplam \\
\hline \multirow{2}{*}{\multicolumn{7}{|c|}{ Samsun }} \\
\hline & & & & & & \\
\hline$(\%)$ & $1,3 \%$ & $0,0 \%$ & $17,7 \%$ & $31,6 \%$ & $49,4 \%$ & $100,0 \%$ \\
\hline \multicolumn{7}{|l|}{ Sivas } \\
\hline$(\%)$ & $7,3 \%$ & $8,2 \%$ & $13,6 \%$ & $32,7 \%$ & $38,2 \%$ & $100,0 \%$ \\
\hline
\end{tabular}

Sivas ilinde konaklayan müşterilerin $\% 70,9^{\prime} \mathbf{u}$ termal suyun kalitesinin kullanım amacına yeterli derecede uygun olduğunu, \%13,6 oranında kararsız kaldığını ve \%15,5'i ise uygun olmadığını belirtmektedir. Samsun ilinde konaklayan müşterilerin ise \%81'i termal suyun kalitesinin kullanım amacına yeterli derecede uygun olduğunu düşünmektedir. Buna karşın \%1,3'lük kısmı uygun olmadığını ve \%17,7 oranında müşteri ise bu konuda kararsız kaldığını belirtmiştir. Tabloya göre Samsun ilinin kaplıca sularının Sivas ilinin kaplıca sularına göre daha kaliteli olduğu düşünülmektedir. 
Tablo 8. Sağlık ve Kür Merkezlerinin Personel Olarak Yeterli Olması İfadesi ile Konaklama Yapılan Yere İlişkin Çapraz Tablo Analizi

$\begin{array}{lccccccc}\begin{array}{l}\text { Sağllk ve kür } \\ \text { merkezlerinin personel } \\ \text { olarak yeterli olmas1 }\end{array} & \mathbf{1} & \mathbf{2} & \mathbf{3} & \mathbf{4} & \mathbf{5} & \text { Toplam } \\ \text { Samsun } & \text { (f) } & 1 & 4 & 19 & 29 & 26 & 79 \\ & \text { (\%) } & 1,3 \% & 5,1 \% & 24,1 \% & 36,7 \% & 32,9 \% & 100,0 \% \\ & \text { (f) } & 4 & 16 & 18 & 38 & 34 & 110 \\ & \text { (\%) } & 3,6 \% & 14,5 \% & 16,4 \% & 34,5 \% & 30,9 \% & 100,0 \%\end{array}$

Otelin sağlık ve kür merkezlerinin personel olarak yeterliliğinde ise her iki il için de aynı oranların olduğu ve otele gelen müşterilerin otelin personel olarak yeterli olduğu konusunda olumlu düşündükleri görülmüştür. Bu oran Sivas ilinde $\% 65,4$ ile yeterli, $\% 16,4$ ile kararsız ve $\% 18,1$ ile de yetersiz olarak belirtilmiştir. Samsun ilin de ise \%69,6 ile yeterli, \%24,1 ile kararsız ve $\% 6,4$ ile de yetersiz olarak belirtilmiştir.

Tablo 9. İllere Göre Otelin Genel Memnuniyet Düzeyi

\begin{tabular}{|c|c|c|c|c|}
\hline \multirow{2}{*}{ T Testi } & $\begin{array}{c}\text { Konaklama } \\
\text { Yapılan Yer }\end{array}$ & $\mathbf{n}$ & Ortalama & Sig \\
\hline \multirow{2}{*}{ Genel Memnuniyet } & Samsun & 79 & 4,1930 & \multirow{2}{*}{$\mathbf{0 , 0 0 1}$} \\
\cline { 2 - 4 } & Sivas & 110 & 3,6977 & \\
\hline
\end{tabular}

Otelin genel memnuniyet faktörü ile iller arasındaki ilişkinin saptanması amacıyla t-testi yapılmıştır. Müşterilerin konakladıkları illere ilişkin verdikleri cevapların ortalamalarına bakıldığında, Samsun'daki otelin genel memnuniyet düzeyinin Sivas'taki otellerden daha iyi olduğu görülmektedir. Samsunda konaklayan müşteriler otelin genel olanaklarından ve hizmetinden Sivas ilinde konaklayan müşterilerden daha memnun ayrılmaktadırlar. Tekrar tercih edilme ve başkalarına önerme konusunda da Samsun ilindeki oteller daha çok tercih edilmektedir. Yine aynı tablodaki verilere bakıldığında $0,001(p<0,05)$ değerinin bulunduğu, genel memnuniyet faktörü ile iller arasındaki değerlendirmede anlamlı bir farklılığın olduğu görülmektedir.

Faktörler ile iller arasındaki ilişkinin saptanması amacıyla t-testi yapılmıştır. Yeterlilik faktörü açısından müşterilerin konakladıkları illere ilişkin verdikleri cevapların ortalamalarına bakıldığında, Samsun ortalama değerlerinin Sivas'tan fazla olduğu görülmektedir. Ancak bu ortalamalar arasında büyük bir farklılık görülmemektedir. Hem Samsun hem de Sivas ilinin personel, sağllk merkezi, kür merkezi, yiyecek içecek kalitesi gibi yeterlilik faktöründe müşterilerin memnun oldukları görülmektedir. Yine aynı tablodaki verilere bakıldığında 0,487 $(p>0,05)$ değerinin bulunduğu, yeterlilik faktörü ile iller arasındaki değerlendirmede anlamlı bir farklılık bulunamamıştır. 
Tablo 10. İllere Göre Ölçeğinin Alt Boyutlarında Otelden Memnuniyet Düzeyi

\begin{tabular}{|c|c|c|c|c|}
\hline T Testi & $\begin{array}{l}\text { Konaklama } \\
\text { Yapilan Yer }\end{array}$ & $\mathbf{n}$ & Ortalama & Sig \\
\hline \multirow{2}{*}{ Yeterlilik } & Samsun & 79 & 4,0174 & \multirow{2}{*}{0,487} \\
\hline & Sivas & 110 & 3,9420 & \\
\hline \multirow{2}{*}{ Fiziksel Olanaklar } & Samsun & 79 & 3,9222 & \multirow{2}{*}{0,090} \\
\hline & Sivas & 110 & 3,7506 & \\
\hline \multirow{2}{*}{ Güven Düzeyi } & Samsun & 79 & 4,1067 & \multirow{2}{*}{0,328} \\
\hline & Sivas & 110 & 4,0013 & \\
\hline \multirow{2}{*}{ Heveslilik } & Samsun & 79 & 4,3544 & \multirow{2}{*}{$0,010^{*}$} \\
\hline & Sivas & 110 & 4,0636 & \\
\hline \multirow{2}{*}{ Empati } & Samsun & 79 & 4,2025 & \multirow{2}{*}{$0,042^{*}$} \\
\hline & Sivas & 110 & 3,9409 & \\
\hline
\end{tabular}

İşletmenin fiziksel imkânları açısından müşterilerin konakladıkları illere ilişkin verdikleri cevapların ortalamalarına bakıldığında, Samsun'daki otelin fiziksel imkânlarının Sivas'taki otellerden daha iyi olduğu görülmektedir. Tablo 10' a göre otopark, telefon, animasyon gibi hizmetlerin beklentileri karşılaması, tedavi ünitelerinin donanımı, termal suyun kalitesi, otelin aydınlık olması, havalandırmasının yeterli düzeyde olması Samsun ilindeki otellerde Sivas ilindeki otellere göre daha iyi olduğu görülmektedir. Yine aynı tablodaki verilere bakıldığında 0,090(p>0,05) değerinin bulunduğu, yeterlilik faktörü ile iller arasındaki değerlendirmede anlamlı bir farklılık bulunamamıştır.

Güven düzeyi açısından müşterilerin konakladıkları illere ilişkin verdikleri cevapların ortalamalarına bakıldığında, Samsun ortalama değerlerinin Sivas'tan biraz daha fazla olduğu görülmektedir. Ancak bu ortalamalar arasında büyük bir farklılık görülmemektedir. Hem Samsun hem de Sivas ilinin güven düzeyi faktöründe müşterilerin memnun oldukları görülmektedir. Yine aynı tablodaki verilere bakıldığında 0,328 (p>0,05) değerinin bulunduğu, yeterlilik faktörü ile iller arasındaki değerlendirmede anlamlı bir farklılık bulunamamıştır.

Sağlık turizmi işletmesinin heveslilik faktörü açısından müşterilerin konakladıkları illere ilişkin verdikleri cevapların ortalamalarına bakıldığında, Samsun'daki otelin heveslilik düzeyinin Sivas'taki otellerden daha yüksek olduğu görülmektedir. Yine aynı tablodaki verilere bakıldığında $0,010 \quad(\mathbf{p}<0,05)$ değerinin bulunduğu, heveslilik faktörü ile iller arasındaki değerlendirmede anlamlı bir farklılığın olduğu görülmektedir.

Otelin empati faktörü açısından müşterilerin konakladıkları illere ilişkin verdikleri cevapların ortalamalarına bakıldığında, Samsun'daki otelin empati düzeyinin Sivas'taki otellerden daha iyi olduğu görülmektedir. Yine aynı tablodaki verilere bakıldığında $0,042 \quad(\mathbf{p}<0,05)$ değerinin bulunduğu, empati faktörü ile iller arasındaki değerlendirmede anlamlı bir farklılığın olduğu görülmektedir.

Korelasyon katsayısında +1 ile -1 arasında değer alır. Korelasyonun +1 olması durumunda değişkenler arasında doğru yönlü ilişki olduğu görülmektedir. - 1 olması durumunda ise değişkenler arasında ters yönlü bir ilişkinin olduğu görülmektedir (Ural ve Kılıç 2006, 247).

Tablo 11'de, müşteri tatmin boyutları arasındaki çoklu korelasyon analizine göre r: 0,790 oranı ile yeterlilik ve güven düzeyi arasında en yüksek pozitif yönde ilişki görülmektedir. Güven düzeyi ve fiziksel imkanlar arasında r: 0,711, yeterlilik ve heveslilik arasında 0,699 heveslilik ile güven düzeyi arasında 0,692, yeterlilik ile fiziksel imkanlar arasında 0,682, empati ile yeterlilik arasında 
0,634, empati ve güven düzeyi arasında 0,543, empati ile fiziksel imkanlar arasında ise 0,459 sonucu çıkmıştır. Yapılan korelasyon analizine göre tüm faktörler arasında pozitif bir ilişki görülmektedir. Bu ise müşteri memnuniyetinde verilen hizmetin her noktasının birbiri ile ilişkili olduğunu ve birinin daha eksik olsa memnuniyeti kapsamlı olarak etkileyeceğini göstermektedir.

Tablo 11. Müşteri Tatmini Değişkenlerine İlişkin Korelâsyon Analizi

\begin{tabular}{|l|c|c|c|c|c|}
\hline \multicolumn{1}{|c|}{ Korelasyon } & $\begin{array}{c}\text { Fiziksel } \\
\text { İmkânlar }\end{array}$ & Güven Düzeyi & Heveslilik & Yeterlilik & Empati \\
\hline $\begin{array}{l}\text { Fiziksel } \\
\text { İmkânlar }\end{array}$ & $\mathbf{1}$ &, $711^{* *}$ &, $554^{* *}$ &, $682^{* *}$ &, $459^{* *}$ \\
\hline Güven Düzeyi & & $\mathbf{1}$ &, $692^{* *}$ &, $790^{* *}$ &, $543^{* *}$ \\
\hline Heveslilik & & & $\mathbf{1}$ &, $699^{* *}$ &, $599^{* *}$ \\
\hline Yeterlilik & & & & $\mathbf{1}$ &, $634^{* *}$ \\
\hline Empati & & & & & $\mathbf{1}$ \\
\hline
\end{tabular}

\section{TARTIŞMA, SONUÇ VE ÖNERİLER}

Sağlık turizmi, turizm çeşitleri içerisinde önemli derecede talebe sahip olan ve sahip olduğu talep potansiyelini her geçen yıl arttıran bir turizm türüdür. Günümüzde diğer turizm yatırımlarında da yaşanan ve sağlık turizmi işletmelerinde benzerlerini gördüğümüz yatırımın karlılığı ve geri dönüşümün hızlandırılması ile dört mevsimde doluluk oranlarının artırılması ve düzenli hale getirilmesi açısından iç ve dış tanıtım, kalite standartlarına sahip olmak ve müşteri ilişkilerinin geliştirilmesi sağlanmalıdır.

Sağlıklı yaşam biçimi davranışlarının artması ile beraber bireylerin sağlık ihtiyaçlarını da her geçen gün artmaktadır. Yaşadıkları bölgede veya ülkede istedikleri sağlık hizmetine kavuşamayan bireyler farklı bölgelere seyahat ederek sağlık hizmeti talebinde bulunurlar. Bireyler yalnızca tedavi amaçlı değil aynı zamanda sağlıklı yaşam sürdürebilmek için de sağlık hizmeti talebinde bulunabilirler. Bu durum günümüzde sağllk turizmi faaliyetlerinin daha fazla önem kazanmasına neden olmuştur (Nagle ve Müller, 2018: 25).

Gerçekleşen talep oranının yüksekliği ve bu turizm türünün günümüz insanları açısından taşıdığı öneme rağmen; termal oteller ve ziyaretçileri üzerine ilgili yazında yapılan araştırmalar, müşteri deneyimleri açısından oldukça sınırlı olduğu görülmektedir. Sağlık turizmi müşterilerinin daha çok yaş olarak da orta ve üst yaş grubundan olan tüketiciler tarafından daha çok tercih edildiği söylenebilir (Sayın vd., 2017). Yapılan çalışmada bunu destekler niteliktedir. Burada özellikle dikkat çeken nokta genç nüfusun payının düşük olmasıdır. Gerçi genelde tedavi amaçlı düşünülen termal tesislere belli yaş ve üstündekilerin gitmesi doğaldır.

Çalışmanın sonuçlarına göre Sivas ve Samsunda sağlık turizmden faydalanan müşterilerin almış oldukları hizmetin müşteri memnuniyetini etkilediği görülmüştür. Konaklama yapılan il ile genel müssteri memnuniyeti, heveslilik ve empati faktörleri arasında anlamlı bir farklılık bulunmuştur. Fakat müşterilerin konaklama yapılan ilin yeterlilik, fiziksel imkanlar ve güven düzeyi faktörlerine göre anlamlı bir farklılık gösterip göstermediğini anlamaya yönelik yapılan test sonucunda grupların sıralama ortalamaları arasındaki fark istatistiksel olarak anlamlı bulunmamiştır. 
Termal turizmde uluslararası ve ulusal talebin belirlenmesi için gerekli çalışmalar yapılmalı, pazarın hedef kitlesi iyi saptanmalı, talebi oluşturan tüketicilerin ekonomik, sosyo-kültürel analizleri yapılarak, gerçekçi ve sürdürülebilir bir fiyat politikası ve pazarlama stratejisi belirlenerek uygulamaya konmalıdır.

Türkiye'de her ne kadar termal turizm faaliyetleri yoğun olarak görünüyor olsa da bazı bölgeler yabancı turistler için çok cazip olarak değerlendirilmemektedir. Bu durum bölgenin yerli veya yabancı turisti ağırlamak için yeterli ve gerekli donanıma sahip olmamasından kaynaklanmaktadır. Sivas ili de buna en iyi örneklerden biridir. Sivas ilinde önemli termal tesisler olmakla beraber bölge halkı dışında yerli veya yabancı turistlerin ilgisi yeterli değildir. Turistlerin ilgisinin artırılması için bölgesel kalkınma planlarının ve stratejilerin yapılması ve yeterli yatırımların ve bölge tanıtımlarının arttırılması önem arz etmektedir. Bununla beraber termal turizmin önemi vurgulanmalı ve bu tesislerin reklamları yapılarak insanların dikkati çekilmelidir. Memnuniyeti artırabilmek için müşterilerin yazılı ve sözlü fikirleri alınmalı ve o doğrultuda düzenlemeler yapılmalıdır.

\section{KAYNAKÇA}

Altunışık, R., Coşkun, R. Bayraktaroğlu, S. ve Yıldırım, E. (2005) Sosyal Bilimlerde Araştırma Yöntemleri: SPSS Uygulamalı. Sakarya: Sakarya Kitabevi, 2005.

Altunışık, R., Özdemir, Ş. ve Torlak, Ö. (2001) Modern Pazarlama. Adapazarı: Değişim Yayınları.

Aydın, O. (2012). Türkiye'de Alternatif Bir Turizm; Sağlık Turizmi .» Karamanoğlu Mehmetbey Üniversitesi Sosyal VeEkonomik Araştırmalar Dergisi, 1 (1) 91-96.

Aymankuy, Y., Akgül, V. ve Can Akgül, C. (2012) Termal Konaklama İşletmelerinde Müşteri Memnuniyetine Etki Eden Unsurlar "Gönen Kaplıcaları Örneği". Balıkesir Üniversitesi Sosyal Bilimler Enstitüsü Dergisi 15 (28): 23-240.

Barca, M., Akdeve, E. ve Gedik Balay, İ. (2013) Türkiye Sağllk Turizm Sektörünün Analizi ve Strateji Önerileri. İşletme Araştırmaları Dergisi, 5(2): 12-20.

Nagle, T. T. and Müller, G. (2018). The Strategy and Tactics of Pricing a Guide to Growing More Profitably., New York and London: Routledge.

Ortiz, M. P., and Garcia, J.A. (2015). Healt And Welness Tourism Emergence of A New Market Segment. Switzerland: Springer international Publishing.

Oyur Çelik, G. (2009). Sağlık Yüksekokulu Öğrencilerinin Sağlı̆̆ı Geliştirme Davranışlarını Etkileyen Etmenlerin İncelenmesi. Anadolu Tibbi Araştırmalar Dergisi 3 (3): 164-169.

Sandıkçı, M., ve Gürpınar, K. (2008). Termal Turizm İşletmelerinde Kür Hizmetlerinin Algılanan Önemi: Ege Bölgesinde Bir Araştırma. Afyon Kocatepe Üniversitesi, İ:İ.B.F. Dergisi, 10 (1): 103-121.

Sayın, K. Ş., Yeginboy, E. Y. ve Yüksel, İ. (2017) Türkiye'de Medikal Turizm Uygulamaları: Bir Üniversite ve İzmir Sağlık Serbest Bölgesi Değerlendirmesi. Dokuz Eylül Üniversitesi İktisadi ve İdari Bilimler Dergisi, 6(2): 25-35.

Tütüncü, Ö. ve İpekgil Doğan, Ö. (2003). Müşteri Tatmini Kapsamında Öğrenci Memnuniyetinin Ölçülmesi ve Dokuz Eylül Üniversitesi Sosyal Bilimler Enstitüsü Uygulaması. Dokuz Eylül Üniversitesi Sosyal Bilimler Enstitüsü Dergisi, 5(1): 130-151.

Uygur, S. M. ve Doğan, S. (2013). Deneyimsel Pazarlamanın Müşteri Memnuniyeti Üzerine Etkisi: Restoranlar Üzerine Bir Araştırma. Dumlupınar Üniversitesi Sosyal Bilimler Dergisi, 37 (1): 33-48. 
Ünal, A. ve Demirel, G. (2013). Sağlık Turizmi İşletmelerinden Yararlanan Müşterilerin Beklentilerinin Belirlenmesine Yönelik Bolu İlinde Bir Araştırma. Electronic Journal of Vocational Colleges, 9 (2): 134-145. 